\title{
Mycobacterium salmoniphilum infection in burbot Lota lota
}

\author{
Mulualem Adam Zerihun',*, Vidar Berg², Jan L. Lyche ${ }^{2}$, Duncan J. Colquhoun, \\ Trygve T. Poppe ${ }^{2}$
}

\author{
${ }^{1}$ The Norwegian Veterinary Institute, Ullevaalsveien 68, 0106 Oslo, Norway \\ ${ }^{2}$ The Norwegian School of Veterinary Science, Ullevaalsveien 72, 0037 Oslo, Norway
}

\begin{abstract}
Burbot Lota lota sampled from lakes Mjøsa and Losna in southeastern Norway between 2005 and 2008 were found to be infected with Mycobacterium salmoniphilum at a culture-positive prevalence of 18.6 and $3.3 \%$, respectively. The condition factor (CF) of mycobacteria-affected fish sampled from Mjøsa in 2008 was lower than the average CF of total sampled fish the same year. Externally visible pathological changes included skin ulceration, petechiae, exopthalmia and cataract. Internally, the infections were associated with capsulated, centrally necrotic granulomas, containing large numbers of acid-fast bacilli, found mainly in the mesenteries, spleen, heart and swim bladder. Mycobacterial isolates recovered on Middlebrook 7H10 agar were confirmed as M. salmoniphilum by phenotypical investigation and by partial sequencing of the $16 \mathrm{~S}$ rRNA, rpoB and Hsp65 genes as well as the internal transcribed spacer (ITS1) locus. This study adds burbot to the list of fish species susceptible to piscine mycobacteriosis and describes $M$. salmoniphilum infection in a non-salmonid fish for the first time.
\end{abstract}

KEY WORDS: Mycobacteriosis - Mycobacterium salmoniphilum - Multi-gene sequencing · Phylogeny $\cdot$ Pathology $\cdot$ Burbot $\cdot$ Lota lota

Resale or republication not permitted without written consent of the publisher

\section{INTRODUCTION}

Burbot Lota lota, the sole member of its genus, is the only truly freshwater gadiform (cod-like) fish, having a circumpolar distribution above latitude $40^{\circ} \mathrm{N}$ (Cohen et al. 1990).

In recent years, burbot populations have been declining in both North America and Europe, with industrial pollution speculated as a possible cause (Pulliainen et al. 1992, Stapanian et al. 2010). Little is known of the natural pathogens of burbot and of the susceptibility of this fish species to pathogenic agents. To the best of our knowledge, the only relevant published work is that of Polinski et al. (2010) in which they investigated the virulence of infectious haematopoetic necrosis virus (IHNV), infectious pancreatic necrosis virus (IPNV), Aeromonas salmonicida, Flavobacterium psychrophilum and Renibacterium salmoninarum in burbot. No overt disease was demonstrated.
The present study was performed as part of a larger investigation into the effects of environmental pollution on fish health in Lake Mjøsa. As preliminary sampling revealed mycobacteriosis in several burbot containing extremely high levels of polybrominated diphenyl ethers (PBDEs) from this lake, sampling was extended to compare the mycobacterial infection status of Lake Mjøsa burbot with burbot from nearby Lake Losna which display background levels of PBDE (Mariussen et al. 2008).

While piscine mycobacteriosis is common in warmer waters (Nigrelli \& Vogel 1963, Hedrick et al. 1987), this disease appears to be relatively uncommon in Europe, particularly in freshwater. Incidences of marine mycobacteriosis in Europe include reports from mackerel Scomber scombrus (presumptive) in the northeast Atlantic (MacKenzie 1988), wild cod in Danish coastal waters (Dalsgaard et al. 1992) and sea-farmed Atlantic salmon Salmo salar (Bruno et al. 1998, Zerihun et al. 
2011b). As far as we are aware, the present report represents the first documentation of mycobacteriosis in a wild, native, northern European fish species and the first report of Mycobacterium salmoniphilum infection in a non-salmonid freshwater fish species.

\section{MATERIALS AND METHODS}

Fish samples. From 2005 to 2008, 58 burbot were sampled from Lake Mjøsa and 30 from Lake Losna. Sampling of the fish was conducted as part of a study of the effects of persistent organic pollutants (POPs) on burbot in both lakes.

Lake Losna is located upstream and in the same water catchment as Lake Mjøsa, which is the largest lake in terms of surface area and the fourth deepest in Norway (Fig. 1). The studied fish from Lake Mjøsa were caught in the vicinity of Vingrom; those from Lake Losna were caught close to the head of the river

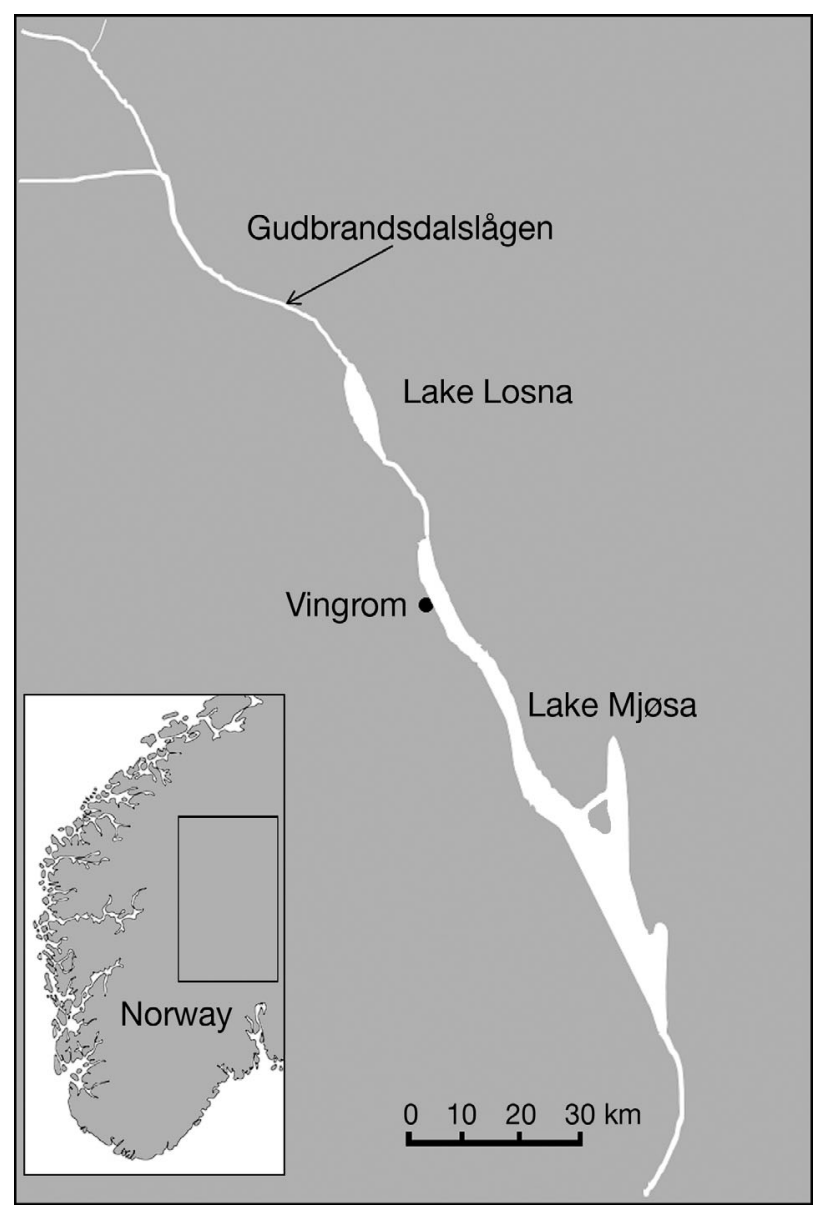

Fig. 1. Sampling sites Lake Mjøsa and Lake Losna, located in eastern Norway. Mjøsa is the largest lake in Norway and Lake Losna is part of the Gudbrandalslågen river catchment, which is the major inflow to Lake Mjøsa
Gudbrandsdalslågen. The fish populations are physically separated by a dam. In both lakes the fish were captured live in fyke nets set at a depth of approximately 10 to $20 \mathrm{~m}$ in Lake Losna and 20 to $40 \mathrm{~m}$ in Lake Mjøsa. The nets were emptied after $10 \mathrm{~d}$ and the fish transported live in iced water to the Norwegian Veterinary Institute (NVI), Oslo, for examination. In addition to burbot, 10 pike Esox lucius were sampled from Lake Mjøsa.

Gross examination. All sampled fish were weighed, measured, and condition factor (CF) was calculated as $\mathrm{CF}=\mathrm{W} \times 100 \times \mathrm{L}^{-3}$, where $\mathrm{W}$ is body weight $(\mathrm{g})$ and $\mathrm{L}$ is length $(\mathrm{cm})$ (Begenal \& Tesch 1978). External and internal macroscopic lesions observed during aseptic necropsies were recorded.

Histopathology. Samples for histopathological examination were taken mainly from fish with macroscopically visible pathological changes in one or more organs. A total of 55 fish, comprising 11 fish from Losna and 44 from Mjøsa, were examined. Tissue samples (head kidney, liver, spleen, heart, mesenteries and intestine, gills, muscle and skin and other organs with visible pathological lesions) were fixed in $10 \%$ buffered formalin for routine paraffin embedding and sectioning. Tissue sections were then examined using light microscopy after staining with haematoxylin and eosin (H\&E) (Luna 1968). Parallel sections were stained with Ziehl-Neelsen (ZN) stain.

Immunohistochemistry. Tissue sections taken from 15 fish with macroscopically visible granulomas were immunostained using genus-specific Mycobacterium polyvalent antisera as described by Zerihun et al. (2011a).

Bacteriology. Blocks of tissue (approximately $0.2 \mathrm{~g}$ ) from kidney, spleen, mesenteries and other organs were taken from all necropsied fish. These tissues were placed into sterile tubes with metal beads (Bertin Technologies) and $1 \mathrm{ml}$ of Butterfield's phosphate buffer (PB) was then added and homogenised using a MagNA Lyser ${ }^{\circledR}$ (Roche). Blood agar with $2 \% \mathrm{NaCl}$ (BAS), without salt (BA), and Middlebrook 7H10 Agar supplemented with Bacto Middlebrook oleic acidalbumin-dextrose-catalase enrichment (MDA) were spread-plated with $0.1 \mathrm{ml}$ homogenate. A series of dilutions $\left(10^{1}\right.$ to $\left.10^{3}\right)$ were prepared from selected tissue homogenates to avoid overgrowth by other bacteria. BA and MDA plates were incubated at $22^{\circ} \mathrm{C}$ and BAS plates at $15^{\circ} \mathrm{C}$. MDA plates were incubated for $8 \mathrm{wk}$ and examined twice weekly. BA and BAS plates were incubated for $10 \mathrm{~d}$. Bacterial isolates were characterised using accepted methods (Kent \& Kubica 1985, Lutz 1992), including Gram and ZN staining. Isolates were inoculated from MDA onto MacConkey agar plates with crystal violet, urea agar and Löwenstein Jensen (LJ) medium, incubated at $28^{\circ} \mathrm{C}$ for up to 
1 mo and checked at least weekly. Recommended positive and negative controls were included in each test. Urease, nitrate reduction, citrate utilisation and iron uptake were also measured and results were validated using positive and negative controls as previously described (Lutz 1992).

DNA extraction. Approximately half of the $10^{1}$ tissue homogenate $(500 \mu \mathrm{l})$ prepared for bacterial culture was placed into FastProtein ${ }^{\mathrm{TM}}$ Blue (Epicentre Biotechnologies) and, following the addition of $500 \mu \mathrm{PB}$, homogenized twice for $45 \mathrm{~s}$ each at $3779 \times g$ using a MagNA Lyser ${ }^{\circledR}$ (Roche). Two full inoculating loops (10 $\mu \mathrm{l}$ each) of bacterial cells were emulsified in $1 \mathrm{ml} \mathrm{PB}$, transferred into FastProtein ${ }^{\mathrm{TM}}$ Blue and homogenized as described above. DNA was extracted from tissue and bacterial homogenates using QuickExract ${ }^{\mathrm{TM}}$ DNA Extraction kit (Epicenter ${ }^{\circledR}$ Biotechnologies) and procedures recommended by the manufacturer.

Real-time PCR. Mycobacterium-specific real-time PCR was carried out on spleen tissue from all sampled fish as described by Zerihun et al. (2011a). DNA extracted from uninfected fish tissues were used as negative controls and were consistently negative. All samples were analysed in duplicate.

Sequence analysis. The 16S rRNA gene of the obtained isolates from plated cultures was amplified using PCR and primers as described by Weisburg et al. (1991). Sequencing of the PCR products was performed using the same primer sets and additional sequencing primers V1, V2, V3, V4, V5 and V6 (Neefs et al. 1993).

Partial sequences of the ITS1, rpoB and Hsp65 genes were amplified and sequenced using primers and procedures described previously (Steingrube et al. 1995, Roth et al. 2000, Adékambi et al. 2003, Gomila et al. 2007). Negative and positive controls were included for each set of amplification. PCR products were purified using the QIAquick PCR Purification Kit (Qiagen), and sequencing was performed using the ABI BigDye Terminator v3.1 Ready Reaction Cycle Sequencing Kit and the ABI PRISM ${ }^{\circledR} 3100$ Genetic Analyser (Applied Biosystems). Sequence fragments obtained in this study were compared with other database entries using BLAST search analysis (Altschul et al. 1997) and deposited in the National Center for Biotechnology Information (NCBI) database with the following accession numbers: for Hsp65, HM638432 to HM638438; ITS1, HM638439 to HM638445; 16 S rRNA, HM638446 to HM638452 and rpoB, HM63638453 to HM638459.

Phylogenetic analysis. Contiguous sequences (NVI6590 to NVI6594, NVI6608 and NVI6609) were assembled using the Sequencher program (Gene Codes Corporation). DNA sequences of $16 \mathrm{~S}$ rDNA, rpoB and Hsp65 were aligned in CLUSTAL_X (Thompson et al. 1997) with related sequences, mainly type strains retrieved from GenBank as included by Whipps et al. (2007). A neighbour-joining phylogenetic tree was generated using the Kimura 3-parameter model in PAUP* version 4.0b10 (Swofford 1998). The strains Mycobacterium tuberculosis H37Rv and M. leprae TN were used as outgroups. Ambiguous and/or missing characters were excluded from the analysis.

\section{RESULTS}

\section{Gross pathology}

Of 58 fish examined from Lake Mjøsa, 20 showed visceral granulomas while 38 showed both visceral granulomas and external lesions. The CF of mycobacteria-affected fish sampled from Mjøsa in 2008 (0.75) was lower than the average CF (0.84) of all fish sampled in Mjøsa the same year. Externally visible pathological changes included skin ulceration, keratitis, petechiae, exophthalmia, vertebral deformity and cataract. Internally, greyish-white nodules (1 to $4 \mathrm{~mm}$ ) were prominent on mesenteries and occasionally in the spleen, liver and heart. One fish showed a large $(>20 \mathrm{~mm})$ grey-brown nodule on the swim bladder (Fig. 2A). A swollen spleen (splenomegaly) was observed in 13 fish from Mjøsa, with some of these fish displaying inflammatory processes of the spleen capsule and adhesion to the mesentery (Fig. 2B). Plerocercoid cysts of the pike tapeworm Triaenophorus nodulosus were observed in the viscera, mainly on mesenteries and serosa of the gastro-intestinal tract (GIT) of the majority of fish sampled from Mjøsa. Fish sampled from Losna $(n=30)$ did not show macroscopically visible pathological changes.

\section{Histopathology}

Granulomas were identified in the visceral organs of 33 out of $44(75 \%)$ fish from Mjøsa and 2 out of 11 $(18.2 \%)$ fish from Losna. Granulomas were mainly observed in the mesenteries and occasionally in the heart, spleen, liver and wall of the GIT (Fig. 3A-D). ZN positive bacilli were visible within granulomas (Fig. 3D) only in culture and real-time PCR positive fish, although not all granulomas from such fish displayed ZN positive bacilli. Several ZN negative tissue sections from culture and PCR positive fish stained positively by immunohistochemistry (IHC). None of the tissue sections from fish taken from Losna stained positively with either ZN or immunostaining.

The observed granulomas appeared to be of the reticuloendothelial (RE) type. Granulomas displayed RE cells and necrotic debris in the centre circumscribed by layers of spindle and epithelioid cells. The 

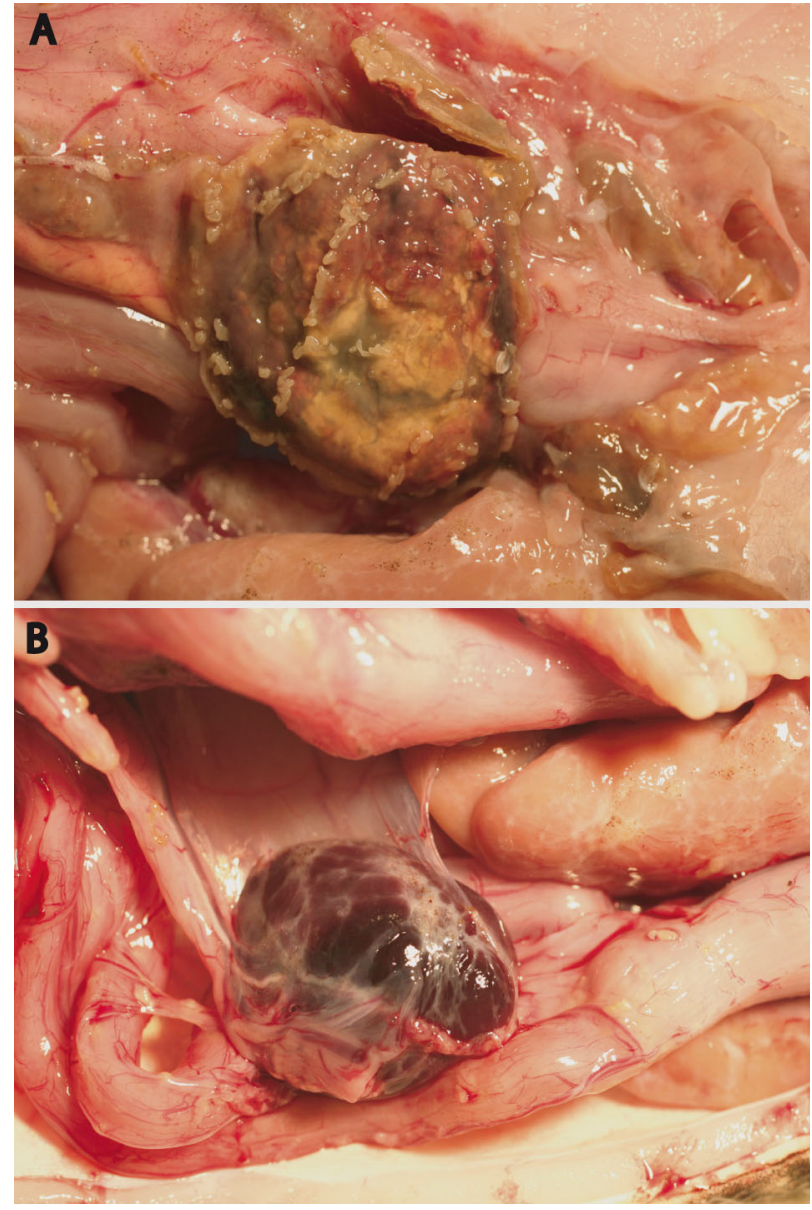

Fig. 2. Lota lota. Burbot sampled from Lake Mjøsa with gross pathology attributed to mycobacterial infection: (A) greyishbrown granulomatous process $(>20 \mathrm{~mm}$ ) on the outer surface (serosa) of the swim bladder and (B) swollen spleen (splenomegaly) with inflammatory process and adhesion to the surrounding mesenteries

outermost zone was encapsulated by thick layers of fibrous tissues (Fig. 3C).

Granulomas were either diffusely scattered in the mesenteries, liver, spleen and heart or were multiple and coalescent (Fig. 3A). Most granulomas were well defined with a clear demarcation towards normal tissue and were typically layered with a caseonecrotic centre (Fig. 3A-C). ZN staining revealed aggregates of acid-fast bacilli in the central parts of the granulomas (Fig. 3D).

\section{Bacteriology and phenotypical characterisation}

Smooth, opaque and creamy colonies with an entire margin were cultivated from the head kidney of 11 out of $59(18.6 \%)$ and 1 out of $30(3.3 \%)$ fish from Mjøsa and Losna, respectively, within $10 \mathrm{~d}$ of incubation at $22^{\circ} \mathrm{C}$ on MDA (Table 1 ). The same bacteria were also cultivated from homogenates of spleen, mesenteries, liver and heart. Bacterial isolates were Gram and ZN positive and showed biochemical characteristics consistent with a Mycobacterium sp. previously isolated from salmonids by Arakawa \& Fryer (1984), Bruno et al. (1998) and Zerihun et al. (2011b) and now recognised as M. salmoniphilum.

\section{Molecular characterisation}

The Mycobacterium-specific real-time PCR conducted on spleen tissue samples revealed positive results in 14 out of 40 (35\%) fish from Lake Mjøsa and 2 out of $30(6.6 \%)$ from Lake Losna (Table 1).

Using conventional PCR, fragments of the 16S rRNA ( 1464 bp), Hsp65 (422 bp) and rpoB (709 bp) genes as well as ITS1 (194 bp) were amplified and sequenced from pure cultures of isolated Mycobacterium sp. The 16S rRNA sequences of all isolates were identical and displayed $100 \%$ identity with $M$. salmoniphilum type strain ATCC $13758^{\mathrm{T}}$ (DQ866768) and reference strain NCIMB 13533 (EF535601). Partial Hsp65 and rpoB gene sequences were also identical, with $r p o B$ showing $99 \%$ and $97 \%$ identity with $M$. salmoniphilum NCIMB13533 and ATCC $13758^{\mathrm{T}}$, respectively, while Hsp65 displayed 99\% identity with ATCC $13758^{\mathrm{T}}$ and $98 \%$ with NCIMB13533. With the exception of isolates NVI6608 and NVI6609, which displayed 4 bp differences, partial ITS1 sequences were also identical and displayed $98 \%$ and $97 \%$ identity with M. salmoniphilum strains NCIMB13533 and ATCC $13758^{\mathrm{T}}$, respectively.

Individual phylogenetic trees were constructed for 16S rRNA, Hsp65 and rpoB genes. All trees supported the phylogenetic topology presented by Whipps et al. (2007) (Fig. 4).

\section{Examination of pike Esox lucius}

No evidence of mycobacterial infection was found following macroscopic, histological bacteriological, or molecular (real-time PCR) studies of the sampled pike.

\section{DISCUSSION}

Mycobacteriosis generally manifests as a sub-acute to chronic disease in both wild and captive fish (Chinabut 1999). The findings in the present study are consistent with the existence of such an infection in burbot from both lakes studied, with a considerably higher prevalence of mycobacteriosis detected in bur- 

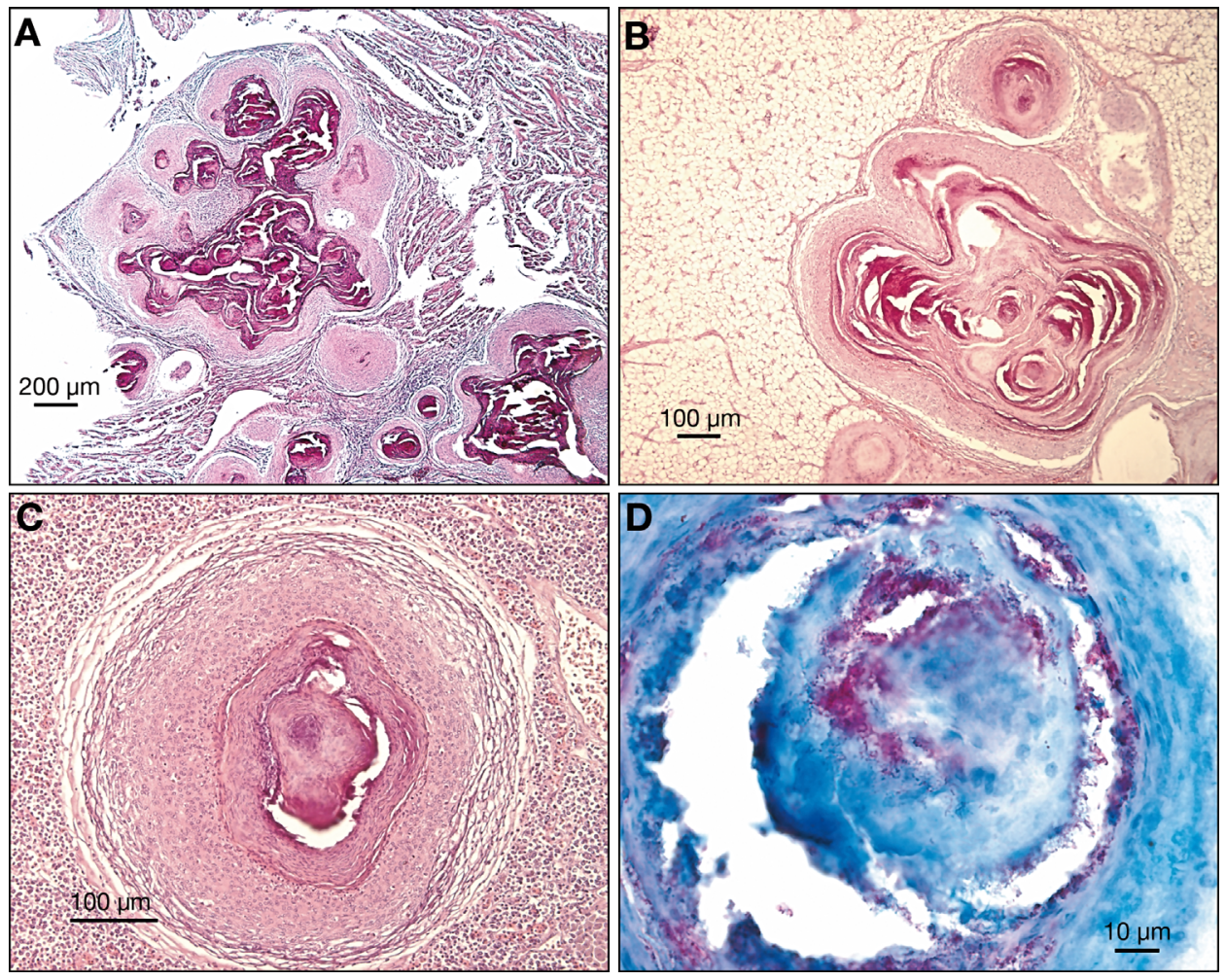

Fig. 3. Lota lota. Histological tissue sections of mycobacteria infected burbot sampled from Lake Mjøsa, showing lesions in (A) heart, (B) liver and (C) spleen tissues. The granulomas on these tissues are well encapsulated with thick (multi-layered) tissue and a necrotic centre. (D) shows granulomas in ZN-stained spleen tissue with a large number of acid-fast bacilli

bot from Lake Mjøsa compared to Lake Losna. Infected fish displayed external and internal, macroscopically and histologically detectable lesions consistent with a long standing infection.

Although further variation in environmental conditions must exist between the 2 lakes, the obvious anthropogenic difference relates to the high levels of environmental pollution in Lake Mjøsa compared to Lake Losna. Previous toxicological analysis of burbot from Mjøsa showed that the levels of PBDEs in this species of fish are extremely high, while the levels of PBDEs in burbot from Lake Losna are in the back-

Table 1. Lota lota. Summary of experimental results in burbot sampled from Lakes Mjøsa and Losna. Gross and histopathological examinations relate to the prevalence of visceral granulomatosis. Real-time PCR relates to positive (threshold cycle number <35) Mycobacterium-specific real-time PCR on fish spleen tissues. Culture results relate to positive culture of $M$. salmoniphilum on Middlebrook 7 H10 from kidney homogenates, and ZN staining relates to observation of acid fast rods in tissue sections. In each case, the number of positive fish out of total fish examined is shown

\begin{tabular}{|lccccc|}
\hline $\begin{array}{l}\text { Sampling } \\
\text { area }\end{array}$ & $\begin{array}{c}\text { Gross } \\
\text { pathology }\end{array}$ & $\begin{array}{c}\text { Histo- } \\
\text { pathology }\end{array}$ & $\begin{array}{c}\text { Real-time } \\
\text { PCR }\end{array}$ & Culture & $\begin{array}{c}\text { ZN } \\
\text { staining }\end{array}$ \\
\hline Lake Mjøsa & $20 / 58$ & $33 / 44$ & $14 / 40$ & $11 / 58$ & $\begin{array}{c}6 / 33 \\
0 / 2\end{array}$ \\
Lake Losna & $0 / 30$ & $2 / 11$ & $2 / 30$ & $1 / 30$ & 0 \\
\hline
\end{tabular}

ground range (Mariussen et al. 2008). Levels of polychlorinated biphenyls (PCBs) and dichloro-diphenyltrichloroethane (DDTs) were also 10 and 15 times higher, respectively, in burbot from Lake Mjøsa compared to Lake Losna, while PBDE levels were 200 times higher in Mjøsa (Gregoraszczuk et al. 2008). Lake Mjøsa is surrounded by 3 cities, industrial areas and farmland. Sources of contamination include sewage, industrial effluents and flood waters from the surrounding area (Løvik et al. 2009).

Although it might be tempting to speculate that the difference in mycobacteriosis prevalence (and incidence of granulomas in general) between the 2 separate burbot populations may be caused by immunosuppression related to environmental pollution, especially in view of the strong association between prevalence and pollution levels, it is not possible to conclude this from the present study. More extensive studies are therefore required to confirm or disprove the association between pollution and mycobacterial infection. Mortality attributed to mycobacteriosis in wild finfish populations is difficult and expensive 
a) 16S rRNA ${ }_{100}$ M. senegalense CIP104941T (AY457081)

57 M. farcinogenes NCTC10955T (AY457084)T

L M. fortuitum CIP104534T (AY457066)

100 M. wolinskyi ATCC700010T (AY457083)

F M. mageritense CIP104973T (AY457076)

56 M. smegmatis ATCC19420T (AY457078)

59 M. septicum ATCC700731T (AY457070)

[L M. peregrinum CIP105382T (AY457069)

66. M. porcinum CIP105392T (AY457077)

94 M. neworleansense ATCC49404T (AY012575)

100M. mucogenicum ATCC49650T (AY457074)

M. phocaicum CIP108542 (AY859682)

74 M. aubagnense CIP108543T (AY859683)

M. salmoniphilum MON (DQ866767)

M. salmoniphilum SIL (DQ866769)

M. salmoniphilum BAN (DQ866765)

M. salmoniphilum ATCC13758T (DQ866768)

M. salmoniphilum MT1900 (EF535602)

79

M. salmoniphilum NCIMB13533 (EF535601)

100

M. leprae TN (AL583920)

-0.001 substitutions site ${ }^{-1}$

c) Hsp65

79 M. peregrinum CIP105382T (AY458069)

85- M. septicum ATCC700731T (AY458066)

- M. porcinum CIP105392T (AY458068)

— M. neworleansense ATCC49404T (AY458076)

98 - M. smegmatis ATCC19420T (AY458065)

79 M. fortuitum CIP104534T (AY458072)

C M. senegalense CIP104941T (AY458067)

$62-M$. wolinskyi ATCC700010T (AY458064)

$99-M$. mucogenicum ATCC49650T (AY458079)

M. phocaicum CIP108542T (AY859676)

M. salmoniphilumAUS (DQ866778)

61 M. salmoniphilum TRA (DQ866783)

81 M. salmoniphilum SIL (DQ866782)

M. salmoniphilum MON (DQ866781)

M. salmoniphilum BAN (DQ866779)

M. salmoniphilum ELK (DQ866780)

$\begin{aligned} 91 & \begin{array}{l}96 \\ \text { M. salmoniphilum MT1900 (EF535604) } \\ \text { M. salmoniphilum NCIMB13533 (EF535603) } \\ \text { NVI6608 }\end{array}\end{aligned}$

| $\mid \begin{aligned} & \text { NVI6608 } \\ & \text { NVI6609 } \\ & \text { NVI659 }\end{aligned}$

$85 \quad \mathrm{NV} 16594$

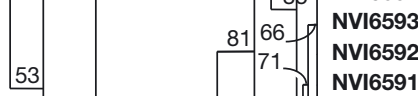

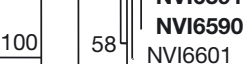

M. salmoniphilum ATCC13758T (DQ866777)

M. immunogenicum CIP106684T (AY458081)

M. chelonae CIP104535T (AY458074)

98- M. abscessus CIP104536T (AY458075)

M. bolletii CIP108541T (FJ607778)

M. tuberculosis H37Rv (BX84257)

M. leprae TN (AL583923)

-0.005 substitutions site ${ }^{-1}$ b) $r p o B \quad 98-$ M. senegalense CIP104941T (AY262738)

65 M. farcinogenes NCTC10955T (AY262742)

87 M. fortuitum CIP104534T (AY147165)

$66 \quad 98-M$. peregrinum CIP105382T (AY147166)

- M. septicum ATCC700731T (AY147167)

M. wolinskyi ATCC700010T (AY262743)

100 M. phocaicum CIP108542T (AY859693)

M. mucogenicum ATCC49650T (AY147170)

$100 \quad \begin{aligned} & 96-\text { M. bolletii CIP108541T(AY859692) } \\ & \text { M. immunogenum CIP06684T (EU109285) }\end{aligned}$

- M. chelonae CIP104535T (AY147163)

100 M. salmoniphilum TRA (DQ866795)

86 M. salmoniphilum SIL (DQ866793)

99 M. salmoniphilum MON (DQ866794)

99 M. salmoniphilum BAN (DQ866792)

6278 M. salmoniphilum ELK (DQ866796)

M. salmoniphilum ATCC13757 (DQ866791)

84 M. salmoniphilum AUS (DQ866797)

NVI6601

9980 NV16591

NVI6592

NVI6593

$99{ }^{8} \mathrm{NVI6594}$

NVI6608

83 NVI6609

M. salmoniphilum NCIMB13533 (EF536970)

M. salmoniphilum ATCC13758T (DQ866790)

M. leprae TN (AL583923)

- 0.01 substitutions site ${ }^{-1}$ M. tuberculosis H37Rv (BX842574)
Fig. 4. Phylogenetic relationships of Mycobacterium salmoniphilum isolated from burbot Lota lota (bold) to other Mycobacterium spp. based on (a) 16S rRNA, (b) $r p o B$ and (c) Hsp65 genes. The neighbour-joining trees were constructed using the Kimura 3-parameter model used on aligned sequences. Numbers at nodes represent bootstrap values (1000 repetitions). $M$. tuberculosis and $M$. leprae were used as outgroups for all trees. GenBank accession numbers for sequences used to construct the trees are shown in parentheses. The bars indicate substitutions per nucleotide position 
to prove conclusively but has been reported (Dalsgaard et al. 1992, Gauthier et al. 2008). While the overall effect on the burbot population of infection with M. salmoniphilum is not known, the relatively high prevalence identified in Lake Mjøsa may well have a detrimental effect on the population as a whole.

Despite the small sample size, the negative test results of mycobacterial infection for the 10 pike analysed in the present study, as well as the results of previous pollutant studies (Gregoraszczuk et al. 2008, Mariussen et al. 2008), provide some support for the presumption that burbot, as a predatory and scavenging bottom-dwelling fish (Paakkonen \& Marjomaki 2000), is more exposed to persistent environmental pollutants than other types of fish.

The granulomas attributed to mycobacterial infection in the present study were composed of a thick capsule of epithelioid cells surrounding a necrotic centre, some of them with large numbers of acid-fast bacilli present, which is consistent with mycobacteriosis in many other fish species (Colorni et al. 1998, Talaat et al. 1998, 1999, Gauthier et al. 2003).

The prevalence of histologically detectable granulomas was considerably higher than the prevalence of mycobacteriosis in fish studied here. Although mycobacteria were not cultured from all granulomatous lesions in this study, Mycobacterium salmoniphilum were cultured only from fish displaying granulomatous lesions, confirming the association of granulomatous lesions with mycobacteria. Granulomas caused by larval stages of the tapeworm Triaenophorus nodulosus were detected in a number of fish from Lake Mjøsa, mainly in the mesenteries and walls of the GIT. A number of histological sections displayed presence of the parasite within the granuloma, which could easily be differentiated from those granulomas associated with mycobacteria. The majority of granulomas with negative mycobacterial test results for culture, ZN staining, IHC and real-time PCR was formed in response to parasitic infections, e.g. tissue encapsulated larval stages of $T$. nodulosus.

Granuloma encapsulation has only occasionally been noted in Mycobacterium salmoniphilum associated disease in salmonids (Bruno et al. 1998, Zerihun et al. 2011b), yet it appears to be a prominent feature of the disease in burbot. This may indicate that this type of response is more related to host species than mycobacterial species.

Phylogenetic analysis of several genetic loci (16S rRNA, Hsp65 and rpoB) confirmed the identity of all isolates recovered during the study as Mycobacterium salmoniphilum (Whipps et al. 2007). However, the variation in ITS1 sequences suggests that more than one clone is involved. Furthermore, our phylogenetic analyses clearly distinguish $M$. salmoniphilum from
M. chelonae, thus corroborating support by Whipps et al. (2007) for the original proposal of M. salmoniphilum as a separate species by Ross (1960), which was not generally accepted at that time. The present study also provides further evidence for M. salmoniphilum as a disease-causing agent in teleost fish. To the best of our knowledge, all isolations of M. salmoniphilum have been made in association with disease in teleost fish and, until the present report, all isolations were related to salmonid fish species (Ross 1960, Bruno et al. 1998, Whipps et al. 2007, Zerihun et al. 2011b). Therefore, as far as we are aware, the present study is the first report of disease caused by $M$. salmoniphilum in a nonsalmonid species. The source of infection in this study is not established.

In conclusion, the present study substantiates burbot, a cold-water fish, as a host species for mycobacteria, and Mycobacterium salmoniphilum as a mycobacterial species which can infect fish species other than salmonids. The high level of contamination detected in the fish from Lake Mjøsa may affect the immune system, leading to the increased prevalence of mycobacterial infection. Further investigation will be needed to determine prevalence of $M$. salmoniphilum in other fish species and environmental samples in the 2 lakes.

Acknowledgements. The authors are grateful to the pathology laboratory staff at the National Veterinary Institute for processing tissue sections. This study was supported by the Norwegian Research Council, project no. 1588823.

\section{LITERATURE CITED}

Adékambi T, Colson P, Drancourt M (2003) rpoB-based identification of non-pigmented and late-pigmenting rapidly growing mycobacteria. J Clin Microbiol 41:5699-5708

Altschul SF, Madden TL, Schaffer AA, Zhang J, Zhang Z, Miller W, Lipman DJ (1997) Gapped BLAST and PSIBLAST: a new generation of protein database search programs. Nucleic Acids Res 25:3389-3402

Arakawa CK, Fryer JL (1984) Isolation and characterization of a new subspecies of Mycobacterium chelonei infectious for salmonid fish. Helgol Meeresunters 37:329-342

Begenal TB, Tesch FW (1978) Methods for assessment of fish production in fresh waters. In: Begenal TB (ed) Age and growth. Blackwell Scientific Publications, Oxford, p 101-136

Bruno DW, Griffiths J, Mitchell CG, Wood BP, Fletcher ZJ, Drobniewski FA, Hastings TS (1998) Pathology attributed to Mycobacterium chelonae infection among farmed salmon and laboratory infected Atlantic salmon Salmo salar. Dis Aquat Org 33:101-109

Chinabut S (1999) Mycobacteriosis and nocardiosis. In: Woo TK, Bruno DW (eds) Fish diseases and disorders, Vol 3. Viral, bacterial and fungal infections. CAB International, New York, NY, p 319-340

Cohen DM, Inada T, Iwamoto T, Scialabba N (1990) FAO species catalogue, Vol 10. Gadiform fishes of the world (Order Gadiformes). An annotated and illustrated cata- 
logue of cods, hakes, grenadiers and other gadiform fishes known to date. FAO Fish Synop 10 (125). FAO, Rome

Colorni A, Avtalion R, Knibb W, Berger E, Colorni B, Timan B (1998) Histopathology of sea bass (Dicentrarchus labrax) experimentally infected with Mycobacterium marinum and treated with streptomycin and garlic (Allium sativum) extract. Aquaculture 160:1-17

Dalsgaard I, Mellergaard S, Larsen JL (1992) Mycobacteriosis in cod (Gadus morhua L.) in Danish coastal waters. Aquaculture 107:211-219

Gauthier DT, Rhodes MW, Vogelbein WK, Kator H, Ottinger CA (2003) Experimental mycobacteriosis in striped bass Morone saxatilis. Dis Aquat Org 54:105-117

Gauthier DT, Latour RJ, Heisey DM, Bonzek CF, Gartland J, Burge EJ, Vogelbein WK (2008) Mycobacteriosis-associated mortality in wild striped bass (Morone saxatilis) from Chesapeake Bay, USA. Ecol Appl 18:1718-1727

Gomila M, Ramirez A, Lalucat J (2007) Diversity of environmental Mycobacterium isolates from hemodialysis water as shown by a multigene sequencing approach. Appl Environ Microbiol 73:3787-3797

Gregoraszczuk EL, Milczarek K, Wójtowicz AK, Berg V, Skaare JU, Ropstad E (2008) Steroid secretion following exposure of ovarian follicular cells to three different natural mixtures of persistent organic pollutants (POPs). Reprod Toxicol 25:58-66

Hedrick RP, McDowell T, Groff J (1987) Mycobacteriosis in cultured striped bass from California. J Wildl Dis 23: 391-395

Kent PT, Kubica GP (eds) (1985) Public health mycobacteriology: a guide for the level III laboratory. US Department of Public Health \& Human Services, Center for Disease Control, Atlanta, GA

Løvik JE, Rognerud S, Fjeld E, Kjellberg G (2009) Mjøsa. Norsk Institutt for Vannforskning (NIVA). September report, available at hedmark.miljostatus.no/Mjosa_JSsnh. pdf.file

Luna LG (1968) Manual of histologic staining methods of the Armed Forces Institute of Pathology. McGraw-Hill, New York, NY

Lutz B (1992) Section 3. Mycobacteriology. In: Isenberg HD (ed) Clinical microbiology procedures handbook, Vol 1. American Society for Microbiology, Washington, DC, p 1-29

MacKenzie K (1988) Presumptive mycobacteriosis in Northeast Atlantic mackerel, Scomber scombrus L. J Fish Biol 32:263-275

Mariussen E, Fjeld E, Breivik K, Steinnes E, Borgen A, Kjellberg G, Schlabach M (2008) Elevated levels of polybrominated diphenyl ethers (PBDEs) in fish from Lake Mjøsa, Norway. Sci Total Environ 390:132-141

Neefs JM, Van de Peer Y, De Rijk P, Chapelle S, De Wachter $R$ (1993) Compilation of small ribosomal subunit RNA structures. Nucleic Acids Res 21:3025-3049

Nigrelli RF, Vogel H (1963) Spontaneous tuberculosis in fishes and other cold-blooded vertebrates with special reference to Mycobacterium fortuitum Cruz from fish and human lesions. Zoologica 48:131-143

Editorial responsibility: David Bruno,

Aberdeen, UK
Paakkonen JPJ, Marjomaki TJ (2000) Feeding of burbot, Lota lota, at different temperatures. Environ Biol Fishes 58: $109-112$

Polinski MP, Fehringer TR, Johnson KA, Snekvik KR and others (2010) Characterization of susceptibility and carrier status of burbot, Lota lota (L.), to IHNV, IPNV, Flavobacterium psychrophilum, Aeromonas salmonicida and Renibacterium salmoninarum. J Fish Dis 33:559-570

Pulliainen E, Korhnonen K, Kankaanranta L, Maeki K (1992) Non-spawning burbot on the northern coast of the Bothnian Bay. Ambio 21:170-175

Ross AJ (1960) Mycobacterium salmoniphilum sp. nov. from salmonid fishes. Am Rev Respir Dis 81:241-250

Roth A, Reischl U, Streubel A, Nauman L and others (2000) Novel diagnostic algorithm for identification of mycobacteria using genus-specific amplification of the 16S-23S rRNA gene spacer and restriction endonucleases. J Clin Microbiol 38:1094-1104

Stapanian MA, Paragamian VL, Madenjian CP, Jackson JR, Lappalainen J, Evenson MJ, Neufeld MD (2010) Worldwide status of burbot and conservation measures. Fish Fish 11:34-56

Steingrube VA, Gibson JL, Brown BA, Zhang Y, Wilson RW, Rajagopalan M, Wallace RG Jr (1995) PCR amplification and restriction endonuclease analysis of a 65-kilodalton heat shock protein gene sequence for taxonomic separation of rapidly growing mycobacteria. J Clin Microbiol 33: 149-153

Swofford DL (1998) PAUP*. Phylogenetic analysis using parsimony (and other methods), version 4 . Sinauer, Sunderland, MA

Talaat AM, Reimschuessel R, Trucksis M (1998) Goldfish, Carassius auratus, a novel animal model for the study of Mycobacterium marinum pathogenesis. Infect Immun 66: 2938-2942

Talaat AM, Trucksis M, Kane AS, Reimschuessel R (1999) Pathogenicity of Mycobacterium fortuitum and Mycobacterium smegmatis to goldfish, Carassius auratus. Vet Microbiol 66: 151-164

> Thompson JD, Gibson TJ, Plewniak F, Jeanmougin F, Higgins DG (1997) The CLUSTAL_X windows interface: flexible strategies for multiple sequence alignment aided by quality analysis tools. Nucleic Acids Res 25:4876-4882

Weisburg WG, Barns SM, Pelletier DA, Lane DJ (1991) 16S ribosomal DNA amplification for phylogenetic study. J Microbiol 173:697-703

> Whipps CM, Butler WR, Pourahmad F, Watral VG, Kent ML (2007) Molecular systematics support the revival of Mycobacterium salmoniphilum (ex Ross 1960) sp. nov., nom. rev., a species closely related to Mycobacterium chelonae. Int J Syst Evol Microbiol 57:2525-2531

Zerihun MA, Hjortaas MJ, Falk K, Colquhoun DJ (2011a) Immunohistochemical and Taqman real-time PCR detection of mycobacterial infections in fish. J Fish Dis 34: 235-246

Zerihun MA, Nilsen H, Hodneland S, Colquhoun DJ (2011b) Mycobacterium salmoniphilum infection in farmed Atlantic salmon Salmo salar. J Fish Dis (in press)

Submitted: January 19, 2011; Accepted: February 16, 2011 Proofs received from author(s): May 13, 2011 